doi: $10.2306 /$ scienceasia1513-1874.2013.39.492

\title{
Examining the physicochemical properties and engine performance of biodiesel from whole seed and extracted kernels of egusi (Citrullus lanatus)
}

\author{
Y.M. Bande ${ }^{\mathrm{a}, *}$, N.M. Adam ${ }^{\mathrm{a}}$, B.O. Jamarei ${ }^{\mathrm{b}}$, Y. Azmi ${ }^{\mathrm{b}}$, S.Z. Razalic \\ a Department of Mechanical and Manufacturing Engineering, Putra University, Malaysia 43400, Sri Serdang, \\ Selangor, Malaysia \\ b Department of Agricultural and Biological Engineering, Putra University, Malaysia 43400, Sri Serdang, \\ Selangor, Malaysia \\ c Material Characterization Laboratories, ITMA, Putra University, Malaysia 43400, Sri Serdang, Selangor, \\ Malaysia
}

*Corresponding author, e-mail: ymbande@yahoo.com

Received 5 Mar 2013

Accepted 8 Jul 2013

\begin{abstract}
Egusi seeds are one of the lesser known, but important sources of oil and protein in Africa. Egusi was grown in Malaysia to observe its adaptation to the local environment and to characterize the properties and biodiesel qualities of its seed oil. Oil from dehulled egusi seed (DESO) and whole egusi seed (WESO) were characterized. Extraction from both samples was done by Soxhlet extractor using n-hexane, and transesterified with KOH. Mean methyl ester (ME) yields from three replications averaged $87.3 \%$ and $86.7 \%$ for DESO-ME and WESO-ME, with cetane numbers of 52.54 and 53.06, respectively. Kinematic viscosities of $4.37 \mathrm{~mm}^{2} / \mathrm{s}$ and $4.39 \mathrm{~mm}^{2} / \mathrm{s}$ were found for WESO-ME and DESOME, respectively, making the former suitable as a bio-lubricant. Average flash points of DESO-ME and WESO-ME were $145.3^{\circ} \mathrm{C}$ and $142.7^{\circ} \mathrm{C}$, with mean densities of $876.7 \mathrm{~kg} / \mathrm{m}^{3}$ and $871.0 \mathrm{~kg} / \mathrm{m}^{3}$, respectively. Six fatty acids were identified via gas chromatography. Total saturated and total unsaturated fatty acids were $20 \%$ and $80 \%$ for DESO-ME, and $21 \%$ and $79 \%$ for WESO-ME. Engine performance tests using pure diesel oil (PDO), B5 (5\% biodiesel, 95\% fossil diesel) and B10 (10\% biodiesel, $90 \%$ fossil diesel) were carried out. Results showed that B5 and B10 of WESO-ME were better than DESO-MEs. The WESO-ME B5 was very similar in performance to PDO. The torques generated by PDO and WESO-ME B5 were the same. The latter had a lower exhaust temperature. However, power output from WESO-ME B5 was lower (by $0.02 \mathrm{~kW})$ and fuel consumption higher by $7 \%$ than for PDO.
\end{abstract}

KEYWORDS: power, torque, fuel consumption, WESO-ME, DESO-ME

\section{INTRODUCTION}

The search for new sources of bio-energy has become more urgent in view of the diminishing levels of adverse environmental effects associated with the use of non-renewable fossil fuels. Biofuels generally offer two-fold advantages over fossil fuels. First, they are renewable. Their by-products are used as animal feed or bio-fertilizers, their production provides employment opportunities, and they are environmental friendly ${ }^{1}$. Biodiesels are predominantly made from the seeds of plants that may be edible, or not. In Europe, USA, and Malaysia, a number of crops, including coconut, rape seed, soy, corn, and oil palm, have been used to produce biodiesels. In India, the most prominents are mahua (Madhuca indica) and jatropha (Jatropha caucas) ${ }^{2}$. Other non-conventional biodiesels sources recently studied includes Arge- mone seed oil ${ }^{3}$, rubber seed oil ${ }^{4}$, and Pongamia pinnata $^{5}$. Some of the highlighted shortcomings of biodiesels are the food- fuel competition caused by their effect on cost, availability, and sustainability ${ }^{6}$. Qualities of good biodiesel include low exhaust emission, biodegradability, and a high cetane number.

One of the lesser-known tropical crops that has recently received the attention of researchers is 'egusi' (Citrullus lanatus); a member of the Cucurbitaceae family. It is grown as a cash crop for its seed in many African countries. The seed serve as a food source after they are dehulled and processed. Originally, egusi was utilized in the manufacturing of soap. It is also used in the making of cosmetics and medicaments $^{7}$. Egusi seed contains about $50 \%$ oil and 30\% protein ${ }^{8}$. It has been suggested that the high content of unsaturated fatty acids in egusi seed may provide a hypocholesteronic effect. 

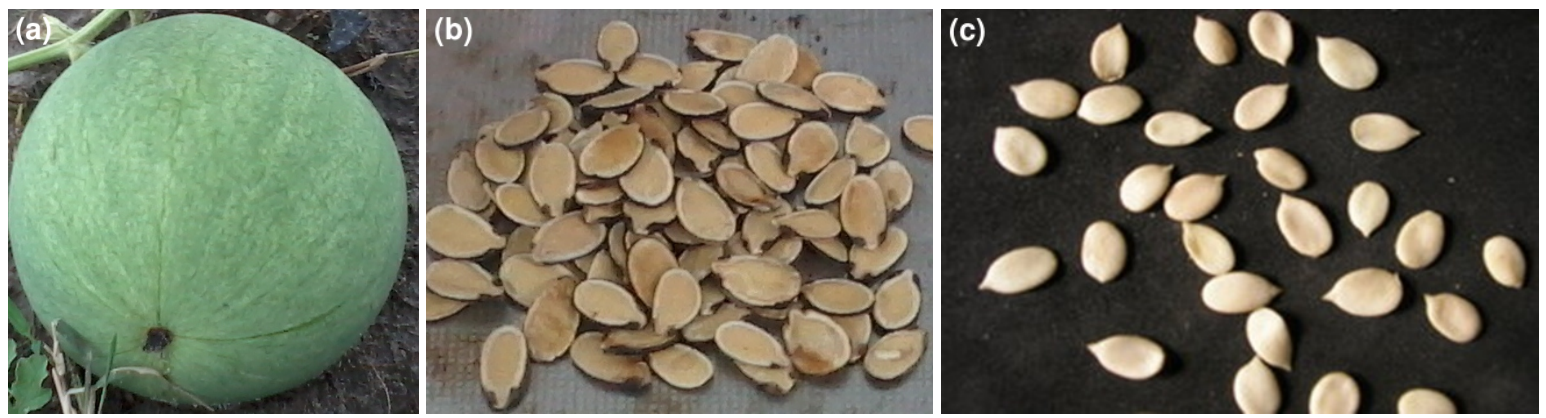

Fig. 1 (a) Egusi fruit, (b) whole seed, and (c) seed kernels.

Egusi melon was reported to have originated in the Western Kalahari region of Namibia and Botswana and the Kalahari Desert areas ${ }^{9}$. These areas include the Sahelian zones, savannahs, and arid areas. Although now recognized as $C$. lanatus (Thunb.) Matsum. \& Nakai, egusi has also been referred to in the literature as C. vulgaris Schrader and C. vulgaris Eckl. and Zeyh., and is sometimes mistaken for other species. Egusi melon is cultivated across Africa, more specifically in West African countries like Nigeria, Togo, Ghana, Benin Republic, Sudan, and Cameroon ${ }^{10,11}$.

The physicochemical properties of egusi oil methyl esters from dehulled (but no whole seed) seed have been studied ${ }^{11}$. Egusi seed are difficult to dehull and this process is typically done manually. On average, $2 \mathrm{~h}$ are required to dehull $1 \mathrm{~kg}$ of whole egusi seed ${ }^{12}$. Egusi was recently introduced into Malaysia in order to characterize its potential as bioenergy source. The specific aim of the research was to extract oil from whole egusi seed and seed kernels, transesterify the crude oils into their methyl esters, and characterize the biodiesel oils using engine performance tests in accordance with ASAE 2001 (SAE J708 FEB 99).

\section{MATERIALS AND METHODS}

The egusi seeds were obtained from Nigeria and planted in Field 2 (Ladang 2) at Putra University, Malaysia. The plants were monitored and grown for 13 weeks. At that time, mature fruits were harvested and processed to obtain seeds. The seeds were cleaned and sun dried to a moisture content of $10 \%$, a level considered safe for long-term storage ${ }^{13}$. Two samples, whole seeds (with hull) and dehulled seeds were used for the experiments. A total of $800 \mathrm{~g}$ of each sample was collected and prepared for experiment. Tests on physicochemical properties of both samples were conducted at the Engineering Faculty laboratories using $\mathrm{KOH}$ as catalyst, $\mathrm{n}$-hexane (95\%), and methanol.

\section{Extraction of oil and evaporation of hexane excess}

One hundred gram samples of whole seed and seed kernels were cleaned, and then coarsely minced at low speed in a blender for $10 \mathrm{~s}$. The condenserincorporated soxhlet extractor was preheated to $80^{\circ} \mathrm{C}$, with round bottom flasks properly placed to evaporate water particles, and then set to $70^{\circ} \mathrm{C}$ (slightly higher than the boiling temperature of the solvent $\mathrm{n}$-hexane ${ }^{14}$ ). The seed samples were placed in the thimbles with $250 \mathrm{ml}$ of n-hexane in round bottom flasks, and extracted for $8 \mathrm{~h}$. Excess hexane was evaporated using a rotary evaporator. The oil/hexane mixture was filtered using a double layer laboratory filter paper (Sigma-Aldrich)

\section{Pre-transesterification and transesterification}

Methods developed at the Palm Oil Research Institute Malaysia (PORIM, 1995), that conform with ASTM D6751 and EN 14214, were utilized for the determination of selected physicochemical properties including kinematic viscosity, acid value, saponification, iodine values, density, and fatty acid profiles ${ }^{11}$. Similar methods were also used for the determination of physicochemical properties of the methyl esters. All experiments were conducted in three replicates, and average values were reported.

Various methods have been reported in the literature to optimize the yield of biodiesel from different seed oils ${ }^{15,16}$. Egusi oil has a low acid value, and therefore a direct alkaline transesterification procedure was adopted, using methanol as a solute and $\mathrm{KOH}$ as a catalyst. Different alcohol/oil ratios, percentage of catalyst, and temperature were evaluated using $20 \mathrm{~g}$ of oil before adopting a method that generated an optimum yield using $\mathrm{KOH}$ as catalyst. The optimum conditions (for both samples) were $0.55 \% \mathrm{KOH}, 7: 1 \mathrm{alcohol} / \mathrm{oil}$ and $65^{\circ} \mathrm{C}$. Fifty grams of whole egusi seed oil (WESO) and dehulled egusi seed oil (DESO) were pre-heated to $70^{\circ} \mathrm{C}$ and stirred at $300 \mathrm{rpm}$ for $15 \mathrm{~min}$. Then, for each mass of 
Table 1 Physicochemical properties of crude oils of WESO and DESO.

\begin{tabular}{|c|c|c|c|c|}
\hline Property & Unit & Standard & WESO & DESO \\
\hline Acid value & $\mathrm{mg} \mathrm{KOH} / \mathrm{g}$ & ASTM D664 ${ }^{18,19}$ & 1.456 & $1.08,0.98^{11}$ \\
\hline Density at $15^{\circ} \mathrm{C}$ & $\mathrm{kg} / \mathrm{m}^{3}$ & ASTM D4052 & 897.96 & $906.82,905.3^{11}$ \\
\hline Iodine value & $\mathrm{g} \mathrm{I}_{2} / 100 \mathrm{~g}$ & - & 116.1 & $114.3,114.46^{11}$ \\
\hline Saponification value & $\mathrm{mg} \mathrm{KOH} / \mathrm{g}$ & - & 201.87 & $212.36,204.44^{11}$ \\
\hline Kinematic viscosity at $40^{\circ} \mathrm{C}$ & $\mathrm{mm}^{2} / \mathrm{s}$ & ASTM D445 & 13.14 & $7.0,31.52^{11}$ \\
\hline Calorific value & $\mathrm{MJ} / \mathrm{kg}$ & ASTM D240 & 45.0 & $41.7,39.37^{11}$ \\
\hline
\end{tabular}

sample (DESO and WESO), $0.55 \%$ catalyst $(\mathrm{KOH})$ of the sample mass and methanol mixture was added to the pre-heated samples. Stirring was continued for $1 \mathrm{~h}$ to ensure complete reaction of the reaction. At that time, the transesterified samples were poured into separating funnels, and left for $8 \mathrm{~h}$ to settle. Two separate layers containing glycerol (bottom layer) and biodiesel (top layer) were observed. The glycerol was removed leaving only the biodiesel in the funnel ${ }^{17}$. The biodiesel was then washed with warm distilled water to remove soap and excess glycerol. The wash procedure was repeated until the distilled water at the lower part of the funnel was clear. One drop of tetraoxosulphate (IV) acid was added to convert the excess glycerol to soap, which was then washed off from the biodiesel, and then oven dried at $65^{\circ} \mathrm{C}$ for $2 \mathrm{~h}$ before drying again over anhydrous $\mathrm{Na}_{2} \mathrm{SO}_{4}$ to remove excess water.

\section{Fatty acids profiling}

Fatty acid profiles were determined using GC, (Shimadzu, Japan), with helium as carrier gas. The fatty acid compositions were determined by converting the two oil samples to fatty acid methyl esters, done by adding $950 \mu \mathrm{l}$ of $\mathrm{n}$-hexane to $50 \mathrm{mg}$ of oil followed by $50 \mu \mathrm{l}$ of $1 \mathrm{ml}$ of sodium methoxide. The mixtures were then vortexed for $5 \mathrm{~s}$ and allowed to settle for $5 \mathrm{~min}$. The top layer $(1 \mu \mathrm{l})$ was then injected into the gas chromatograph to obtain FA methyl ester peaks. The retention times of the peaks obtained were then compared with standard peaks for identification.

\section{Properties of WESO and DESO biodiesels}

Properties of whole egusi melon seed oil methyl ester (WESO-ME) and dehulled egusi melon seed oil methyl ester (DESO-ME) were determined according to ASTM D6751 and EN 14214 standards. These properties included; acid value (EN 14104), cloud and pour points (ASTM D2500), calorific values (ASTM D240), density (ASTM D4052), flash point (ASTM D93), kinematic viscosity (ASTM D445), saponification value, and iodine value.

\section{Engine test bed}

A single cylinder four-stroke diesel engine with the following specifications was used: Model: L48N, brand: Yanmar Engines, bore: $70 \mathrm{~mm}$, stroke: $57 \mathrm{~mm}$, displacement: $219 \mathrm{cc}$, maximum output: $3.1 \mathrm{~kW} / 3000 \mathrm{rpm}$.

Engine test bed has the following specifications: Eddy current dynamometer brand: Xiang Yi, eddy current dynamometer model: GW 10, rated absorbing power: $10 \mathrm{~kW}$, rated maximum speed: $13000 \mathrm{rpm}$, measuring accuracy of torque: $\pm 0.2-0.3 \%$, measuring accuracy of rotational speed: $\pm 1 \mathrm{rpm}$, air inlet pipe internal diameter: $54.8 \mathrm{~mm}$, airflow meter range: $0-10 \mathrm{~m} / \mathrm{s}$, air temperature range: $0-100{ }^{\circ} \mathrm{C}$, fuel consumption weighing balance: $6100 \times 0.1 \mathrm{~g}$, engine coolant: water.

\section{RESULTS AND DISCUSSION \\ Properties of crude WESO and DESO}

The physicochemical properties of the crude oils are shown in Table 1. Acid values of the samples were 1.45 and $1.08 \mathrm{mg} \mathrm{KOH} / \mathrm{g}$ for WESO and DESO, respectively. This corresponds to $0.728 \%$ and $0.54 \%$ free fatty acid. Low free fatty acid oils do not require double-stage acid-alkaline transesterification ${ }^{13,20,21}$. The density and saponification values of the WESO were lower than those of the DESO by $8.86 \mathrm{~kg} / \mathrm{m}^{3}$ and $10.76 \mathrm{mg} \mathrm{KOH} / \mathrm{g}$, respectively, with iodine value higher in WESO by $1.8 \mathrm{~g} \mathrm{I}_{2} / 100 \mathrm{~g}$. Similarly, kinematic viscosities were $13.14 \mathrm{~mm}^{2} / \mathrm{s}$ and $7.0 \mathrm{~mm}^{2} / \mathrm{s}$, with calorific values of $45.0 \mathrm{MJ} / \mathrm{kg}$ and $41.7 \mathrm{MJ} / \mathrm{kg}$ for WESO and DESO, respectively. All readings were in agreement with the literature on melon seed oil $^{2,11,22-25}$.

\section{Fatty acids profiles of DESO-ME and WESO-ME}

Six fatty acids were identified in both the DESOME and the WESO-ME samples. These were C16:0, C16:1, C18:0, C18:1, C18:2, and C18:3 (palmitic, palmitoleic, stearic, oleic, linoleic, and linolenic, respectively). Total saturated and unsaturated acids 
Table 2 Fatty acids components of some vegetable oils, DESO-ME and WESO-ME.

\begin{tabular}{lcccccccc}
\hline Fatty acid (group) & Jatropha $^{17}$ & Safflower $^{19}$ & Sunflower $^{19}$ & Soybean $^{19}$ & EMOME $^{11}$ & EMOME $^{14}$ & DESO-ME & WESO-ME \\
\hline Palmitic (C16:0) & 18.22 & 6.6 & 6.0 & 10.3 & 10.48 & 13.5 & 10.22 & 11.62 \\
Palmitoleic (C16:1) & 0.0 & 0.0 & 0.0 & 0.0 & 0.06 & 13.7 & 0.07 & 0.08 \\
Stearic (C18:0) & 5.14 & 3.3 & 5.9 & 4.7 & 9.72 & - & 9.78 & 9.53 \\
Oleic (C18:1) & 28.46 & 14.4 & 16.0 & 22.5 & 17.95 & 14.6 & 16.50 & 16.56 \\
Linoleic (C18:2) & 48.18 & 75.5 & 71.4 & 54.1 & 61.41 & 56.9 & 63.39 & 62.12 \\
Linolenic (C18:3) & 0.0 & 0.1 & 0.6 & 8.3 & 0.38 & 0.5 & 0.04 & 0.09 \\
Total saturated & 23.36 & 10.00 & 12.00 & 15.10 & 20.20 & 28.10 & 20.00 & 21.15 \\
Total unsaturated & 76.64 & 90.00 & 88.00 & 84.90 & 79.80 & 71.90 & 80.00 & 78.85 \\
\hline
\end{tabular}

Table 3 Fuel properties of DESO-ME and WESO-ME and other biodiesels.

\begin{tabular}{|c|c|c|c|c|c|c|c|c|}
\hline \multirow[t]{2}{*}{ Property } & \multicolumn{2}{|c|}{ Standards Limits } & \multirow[t]{2}{*}{ DESO-ME } & \multirow[t]{2}{*}{ WESO-ME } & \multirow[t]{2}{*}{ EMOME } & \multirow[t]{2}{*}{$\mathrm{PME}^{\mathrm{a}}$} & \multirow[t]{2}{*}{$\mathrm{SnME}^{\mathrm{a}}$} & \multirow[t]{2}{*}{$\mathrm{SfME}^{\mathrm{a}}$} \\
\hline & ASTM D6751 & EN 14214 & & & & & & \\
\hline Acid value (mg KOH/g) & $0.5 \max$ & $0.5 \max$ & 0.168 & 0.14 & $0.19^{11}$ & - & $0.4^{34}$ & $0.28^{35}$ \\
\hline Linolenic Acid $(\%(\mathrm{~mol} / \mathrm{mol}))$ & - & $12 \max$ & 0.04 & 0.09 & $0.38^{11}$ & - & $0.2^{34}$ & - \\
\hline $\mathrm{K} /$ viscosity at $40^{\circ} \mathrm{C}\left(\mathrm{mm}^{2} / \mathrm{s}\right)$ & $1.9-6.0$ & $3.5-5.0$ & 4.39 & 4.37 & $3.83^{11}$ & $7.532^{1}$ & $4.85^{36}$ & $4.29^{35}$ \\
\hline Density at $15^{\circ} \mathrm{C}\left(\mathrm{kg} / \mathrm{m}^{3}\right)$ & - & $860-900$ & 876.7 & 871.0 & $883^{11}$ & $905.4^{1}$ & $884^{36}$ & $874^{35}$ \\
\hline Flash point $\left({ }^{\circ} \mathrm{C}\right)$ & $130 \mathrm{~min}$ & $120 \mathrm{~min}$ & 145.3 & 142.7 & $142.0^{11}$ & $90^{1}$ & $168^{36}$ & $176^{35}$ \\
\hline Cloud point $\left({ }^{\circ} \mathrm{C}\right)$ & -3 to 12 & Report & 10 & 8 & $0.5^{11}$ & $-6.5^{1}$ & $1^{36}$ & $2^{35}$ \\
\hline Calorific value (MJ/kg) & - & - & 45.52 & 45.72 & $39.97^{11}$ & - & $45.5^{35}$ & $45.21^{35}$ \\
\hline Pour point $\left({ }^{\circ} \mathrm{C}\right)$ & -15 to 10 & - & -7 & -1 & $-6^{1}$ & $-13^{1}$ & - & - \\
\hline Ester content $(\%(\mathrm{~mol} / \mathrm{mol}))$ & - & $96.5 \mathrm{~min}$ & 97.27 & 97.19 & $96.78^{11}$ & - & $97.2^{34}$ & $97.67^{35}$ \\
\hline Cetane number & $47-65$ & - & $52.54^{\mathrm{b}}$ & $53.06^{\mathrm{b}}$ & $53.66^{11}$ & $53^{1}$ & $55^{36}$ & $52.32^{35}$ \\
\hline
\end{tabular}

${ }^{\text {a }} \mathrm{PME}=$ pongamia methyle ester, SnME = sunflower methyl ester, SfME = safflower methyl ester.

${ }^{\mathrm{b}}$ Cetane numbers of DESO-ME and WESO-ME, determined empirically as sourced from Refs. 30, 31, 34.

were $20 \%$ and $80 \%$ for DESO-ME and $21 \%$ and $79 \%$ for WESO-ME, respectively. Unsaturated fatty acids included palmitic and stearic acids. These accounted for $10.2 \%$ and $9.8 \%$ for DESO-ME and $11.6 \%$ and $9.5 \%$ for WESO-ME. Linoleic acid was the predominant fatty acid in both DESO-ME and WESO-ME at concentrations of $63.4 \%$ and $62.1 \%$, respectively. Various other oils like safflower, sunflower, rape seed, and jatropha contain unsaturated acids at similar levels ${ }^{26-28}$. For purposes of comparison, Table 2 highlights the properties of DESO-ME and WESO-ME with methyl esters of some other seed oils. The literature has shown that a high percentage of linoleic and oleic acid in beneficial for a higher quality biodiesel $^{29,30}$. The oleic and linoleic acid values for both DESO-ME and WESO-ME were $16.6 \%$ and $63.5 \%$ and $16.6 \%$ and $62.1 \%$, respectively.

\section{Biodiesel yields and fuel properties of DESO-ME and WESO-ME}

Biodiesel yield is expressed in percentage of the ratio of weight of methyl ester obtained after purification to the weight of the oil used in the reaction ${ }^{15,31}$. DESO-
ME and WESO-ME yields were determined to be $87.3 \%$ and $86.7 \%$, respectively. Yields from other oil seeds were similar: Pongamia pinnata L., $90 \%{ }^{5}$; palm oil, $83 \%^{28}$; tobacco seed oil, $84 \%^{29}$; sesame seed oil, $30 \%{ }^{32}$; and karanya, $86 \%^{33}$. Fuel properties of DESO-ME and WESO-ME are described in Table 3, in comparison with other selected seed oils, with the standard limits per ASTM D6751 and EN 14214.

Acid values of biodiesels from DESO-ME and WESO-ME are also presented in Table 3. Acid values were within the ranges specified in ASTM D6751 and EN 14214 (0.5 max). Acid value is the measure of the milligrams of $\mathrm{KOH}$ required to neutralize $1 \mathrm{~g}$ of free fatty acid. Previous studies on egusi oil ${ }^{11}$ from dehulled seed were also within this range, but lower than that of sunflower ${ }^{34}$ and safflower ${ }^{35}$. Acid values of $0.168 \mathrm{mg} \mathrm{KOH} / \mathrm{g}$ for DESO-ME and $0.14 \mathrm{mg} \mathrm{KOH} / \mathrm{g}$ for WESO-ME suggest that egusi can provide good biodiesel. Higher acid values lead to polymerization and catalyse the hydrolysis of biodiesel.

Vegetable oils and animal fats are sources of oils that are typically used in the production of biodiesel. Their favourable flow characteristics and their ease 
of atomization and combustion make these sources of oil especially suitable as biodiesels. Kinematic viscosity $(\mathrm{KV})$ is one of the principal characteristics used to evaluate biodiesels. The standard limits have been defined as 1.9-6.0 (ASTM D6751) and 3.5-5.0 (EN 14214) at $40^{\circ} \mathrm{C}$. The KV values for DESO-ME and WESO-ME were $4.39 \mathrm{~mm}^{2} / \mathrm{s}$ and $4.37 \mathrm{~mm}^{2} / \mathrm{s}$ at $40{ }^{\circ} \mathrm{C}$, respectively. The value for DESO-ME falls within both standards, while WESO-ME falls within the ASTM D6751 standards only. Both KVs were lower than values in safflower ${ }^{35}$ and sunflower ${ }^{36}$, lower $\mathrm{KV}$ is better in biodiesel.

Another important property of biodiesel fuels is their flash point. This is, the temperature at which the fuel will ignite when exposed to flame. The flash point of a good biodiesel should be higher than that of fossil diesel oil, making it safer for handling and transportation. The minimum standards have been established as $130{ }^{\circ} \mathrm{C}$ and $120^{\circ} \mathrm{C}$ in ASTM D6751 and EN 14214, respectively. In this study, we found the flash points for DESO-ME and WESO-ME to be $145.3^{\circ} \mathrm{C}$ and $142.7^{\circ} \mathrm{C}$, respectively. Flash points of sunflower, jatropha, soybean, Pongamia pinnata and palm were determined to be $180^{\circ} \mathrm{C}, 163^{\circ} \mathrm{C}, 160^{\circ} \mathrm{C}$, $141{ }^{\circ} \mathrm{C}$, and $135^{\circ} \mathrm{C}$, respectively ${ }^{37}$.

Cloud point (CP) measures the temperature at which biodiesel will begin to solidify, and its pour point (PP) is that temperature at which the fuel ceases to flow. Usually, the PP is lower than the CP. ASTM D6751 established limits of $-3{ }^{\circ} \mathrm{C}$ to $12{ }^{\circ} \mathrm{C}$ and $-15^{\circ} \mathrm{C}$ to $10^{\circ} \mathrm{C}$ for $\mathrm{CP}$ and PP, respectively, with no limits established in EN 14214 (the manufacturer of biodiesel report to potential buyers). Biodiesels from the current work showed the cloud point and pour point for DESO-ME were $10^{\circ} \mathrm{C}$ and $-7^{\circ} \mathrm{C}$ and WESO-ME were $8{ }^{\circ} \mathrm{C}$ and $-1^{\circ} \mathrm{C}$ on average of three replicates. Density of fuel is another important parameter in selecting a biodiesel since measures the mass of fuel per unit volume. The limit for EN 14214 was $860-900 \mathrm{~kg} / \mathrm{m}^{3}$. Densities of DESO-ME and WESO-ME in the current work were 876.70 and $870.96 \mathrm{~kg} / \mathrm{m}^{3}$, respectively, both values falling within the standard range. For comparison, densities of safflower and sunflower were reported ${ }^{35,36}$ as $884 \mathrm{~kg} / \mathrm{m}^{3}$ and $874 \mathrm{~kg} / \mathrm{m}^{3}$.

Calorific value represents the energy released when a gram unit of sample is burnt in the presence of oxygen, releasing $\mathrm{CO}_{2}$ and $\mathrm{H}_{2} \mathrm{O}$. The heating value for DESO-ME and WESO-ME were $45.52 \mathrm{MJ} / \mathrm{kg}$ and $45.72 \mathrm{MJ} / \mathrm{kg}$, respectively, when measured in accordance with ASTM D240 standards. The heating value of egusi melon methyl ester generated $39.0 \mathrm{MJ} / \mathrm{kg}^{11}$ for Nigerian grown egusi, while safflower generated
$45.21 \mathrm{MJ} / \mathrm{kg}^{35}$ and sunflower generated $45.5 \mathrm{MJ} / \mathrm{kg}^{36}$.

A good fuel (fossil or bio-derived) should have a high cetane number. The ASTM D6751 suggests a range of 47-65 in order to qualify a biodiesel. Cetane numbers of both DESO-ME and WESOME were determined empirically ${ }^{31,34}$. Cetane numbers for DESO-ME and WESO-ME were 52.54 and 53.06, respectively, both falling within the standards (Table 3). A previous reports for egusi melon methyl ester was indicated to have cetane number of 53.66 for Nigerian egusi ${ }^{11}$. In contrast, values of $53^{5,35}$, $52.32^{36}$ and $55^{36}$ were reported for Pongania pinnata, safflower, and sunflower ${ }^{36}$, respectively. Unsaturated compounds typically have higher cetane numbers ${ }^{37}$.

\section{Engine performance of biodiesel blends}

A single cylinder diesel engine was tested according to ASAE 2001 (SAE J708 FEB 99) standards. The procedures described in the standards were as follows:

Maximum power-fuel consumption: The purpose of this run is to determine the maximum power as delivered through a mechanical power outlet to a dynamometer at the manufacturer's specified engine or mechanical power outlet speed; and to record the corresponding fuel consumption.

Varying power-fuel consumption: The purpose of this run is to determine the fuel consumption and speed when power is varied. The run shall consist of six power settings, each to be run for a fixed number of minutes in the following order:

1. $85 \%$ of dynamometer torque at maximum power.

2. Zero dynamometer torque.

3. One-half of $85 \%$ of dynamometer torque obtained at maximum power.

4. Dynamometer torque obtained at maximum power. 5. One-quarter of $85 \%$ of dynamometer torque obtained at maximum power.

6. Three-quarter of $85 \%$ dynamometer torque obtained at maximum power.

Maximum power-fuel consumption test: Table 4 provides data on the fuel consumption of the engine at maximum power using pure diesel oil (PDO), DESO-ME (B5 and B10) and WESO-ME (B5 and B10). The specific fuel consumption (SFC) on PDO at maximum power was $0.2452 \mathrm{~kg} / \mathrm{kWh}$. For DESOME B5 and B10, the mean SFC were $0.2906 \mathrm{~kg} / \mathrm{kWh}$ and $0.2958 \mathrm{~kg} / \mathrm{kWh}$, while WESO-ME B5 and B10 had 0.2561 and $0.2638 \mathrm{~kg} / \mathrm{kWh}$, respectively, on three replicate runs. The SFC of WESO-ME blends were close to PDO. The highest mean exhaust temperature was recorded for PDO at $183.7^{\circ} \mathrm{C}$ with minimum on 
Table 4 Analysis of maximum power-fuel consumption for $300 \mathrm{~s}$ : Summary of results from three replicates.

\begin{tabular}{lcccccccccccc}
\hline Sample & $\begin{array}{c}\mathrm{MT}^{\mathrm{a}} \\
(\mathrm{Nm})\end{array}$ & $\mathrm{SD}$ & $\begin{array}{c}\mathrm{MP}^{\mathrm{a}} \\
(\mathrm{W})\end{array}$ & $\mathrm{SD}$ & $\begin{array}{c}\mathrm{ML}^{\mathrm{a}} \\
(\mathrm{N})\end{array}$ & $\mathrm{SD}$ & $\begin{array}{c}\mathrm{MET}^{\mathrm{a}} \\
\left({ }^{\circ} \mathrm{C}\right)\end{array}$ & $\begin{array}{c}\mathrm{SD} \\
\mathrm{MFU}^{\mathrm{a}}\end{array}$ & $\begin{array}{c}\mathrm{SD} \\
(\mathrm{g})\end{array}$ & $\begin{array}{c}\text { Fuel flow } \\
(\mathrm{g} / \mathrm{s})\end{array}$ & $\begin{array}{c}\mathrm{SFC}^{\mathrm{a}} \\
(\mathrm{kg} / \mathrm{kWh})\end{array}$ \\
\hline PDO & 10.20 & - & 3001.1 & 1.0 & 10.67 & 0.06 & 183.7 & 1.5 & 61.33 & 0.06 & 0.204 & 0.2452 \\
DESO-ME B5 & 9.73 & 0.06 & 2861.7 & 3.0 & 10.17 & 0.06 & 174.5 & 1.1 & 69.30 & 0.10 & 0.231 & 0.2906 \\
DESO-ME B10 & 9.87 & 0.06 & 2888.9 & 0.9 & 10.3 & 0.0 & 168.5 & 0.7 & 71.20 & 0.10 & 0.237 & 0.2958 \\
WESO-ME B5 & 10.20 & - & 2981.3 & 1.0 & 10.57 & 0.15 & 152.5 & 1.1 & 65.53 & 0.15 & 0.218 & 0.2561 \\
WESO-ME B10 & 9.33 & 0.06 & 2976 & 11 & 9.87 & 0.06 & 146.3 & 1.0 & 63.50 & 0.10 & 0.212 & 0.2638 \\
\hline
\end{tabular}

${ }^{\mathrm{a}} \mathrm{MT}=$ mean torque, $\mathrm{MP}=$ mean power, $\mathrm{ML}=$ mean load, MET = mean exhaust temp., $\mathrm{MFU}=$ mean fuel used, $\mathrm{SFC}=$ specific fuel consumption.

Table 5 Pure diesel oil (PDO) results of varying power engine performance for $300 \mathrm{~s}$.

\begin{tabular}{lcccccccccccc}
\hline Torque & $\begin{array}{c}\mathrm{MP}^{\mathrm{a}} \\
(\mathrm{W})\end{array}$ & $\mathrm{SD}$ & $\begin{array}{c}\mathrm{MS}^{\mathrm{a}} \\
(\mathrm{rpm})\end{array}$ & $\mathrm{SD}$ & $\begin{array}{c}\mathrm{ML}^{\mathrm{a}} \\
(\mathrm{N})\end{array}$ & $\mathrm{SD}$ & $\begin{array}{c}\mathrm{MET}^{\mathrm{a}} \\
\left({ }^{\circ} \mathrm{C}\right)\end{array}$ & $\mathrm{SD}$ & $\begin{array}{c}\mathrm{MFU}^{\mathrm{a}} \\
(\mathrm{g})\end{array}$ & $\begin{array}{c}\mathrm{SD} \\
\text { Fuel flow }\end{array}$ & $\begin{array}{c}\mathrm{SFC}^{\mathrm{a}} \\
(\mathrm{g} / \mathrm{s})\end{array}$ \\
\hline 8.67 & 2335 & 5 & 2938 & 28 & 8.807 & 0.015 & 195 & 4 & 48.5 & 0.3 & 0.162 & 0.2493 \\
0.00 & 0 & 0 & 2999 & 1 & 0 & 0 & 124 & 1 & 23 & 0 & 0.077 & 0 \\
4.34 & 1245 & 5 & 2961 & 4 & 4.513 & 0.015 & 148.3 & 1.5 & 36.33 & 0.12 & 0.121 & 0.3501 \\
10.20 & 2889 & 3 & 2895 & 5 & 10.750 & 0.012 & 202.3 & 5.9 & 52 & 2 & 0.173 & 0.2160 \\
2.17 & 622.1 & 1.9 & 2977 & 3 & 2.353 & 0.015 & 126.7 & 1.5 & 28.0 & 0.2 & 0.093 & 0.5401 \\
6.50 & 1777 & 4 & 2932 & 3 & 6.83 & 0.02 & 171.3 & 1.5 & 44.47 & 0.12 & 0.148 & 0.3002 \\
\hline
\end{tabular}

${ }^{\text {a }} \mathrm{MP}=$ mean power, $\mathrm{MS}=$ mean speed, $\mathrm{ML}=$ mean load, MET = mean exhaust temp., MFU = mean fuel used, $\mathrm{SFC}=$ specific fuel consumption.

WESO-ME B5. Maximum SFC of all blends was with DESO-ME B10 at $0.2958 \mathrm{~kg} / \mathrm{kWh}$ with mean load of $10.3 \mathrm{~N}$.

The mean torques produced by PDO, DESO-ME B5, DESO-ME B10, WESO-ME B10 and WESOME B5 samples was 10.20, 9.73, 9.87, 9.33, and $10.20 \mathrm{Nm}$, respectively. The mean torque generated by the WESO-ME B5 especially, was similar as that of PDO. Similarly, the mean power generated by PDO was $3.0 \mathrm{~kW}$, while DESO-ME and WESO-ME generated about $2.98 \mathrm{~kW}$, but DESO-ME had less mean torque. The properties of WESO-ME B5 were close to that of PDO in terms of mean torque, mean power generated, mean load and mean fuel used and so was the mean exhaust temperature generated. Results on Table 4 indicate the WESO-ME B5 and B10 blends were slightly better in performance that the DESOME B5 and B10 blend. This led to conducting the second level of tests on WESO-ME B5 and B10, in comparison with PDO.

Varying power-fuel consumption tests: Table 5 summarizes the results of the varying power fuel consumption test using PDO, following standardized procedures. At maximum power, $10.20 \mathrm{Nm}$ of torque was generated, while at $85 \%$ power, $8.67 \mathrm{Nm}$ of torque was generated (mean SFC of $0.2493 \mathrm{~kg} / \mathrm{kWh}$ ). Mean power generated at $8.67 \mathrm{Nm}$ torque was $2335 \mathrm{~W}$ (Table 5). With no torque, the generated power was $0 \mathrm{~W}$ and the SFC was also $0 \mathrm{~kg} / \mathrm{kWh}$. The lowest mean engine speed provided at maximum engine torque of 10.2 Nm, and as the torque declined to 0 , the engine speed approached $3000 \mathrm{rpm}$.

Table 6 summarizes the performance of WESOME B10 on the same engine. The torque generated at maximum engine speed in this case was $9.4 \mathrm{Nm}$ at $2985 \mathrm{~W}$. At maximum engine speed, the mean exhaust temperature was $198.7^{\circ} \mathrm{C}$, which indicate heating contribution to the environment. The SFC was $0.2246 \mathrm{~kg} / \mathrm{kWh}$ at $2985 \mathrm{~W}$ mean power. At $85 \%$ power, $8.0 \mathrm{Nm}$ of torque was generated and the power declined to $2452 \mathrm{~W}$. The mean exhaust temperature declined to $195.3^{\circ} \mathrm{C}$ while the SFC increased to $0.2431 \mathrm{~kg} / \mathrm{kWh}$. The highest $\mathrm{SFC}$ was recorded as $0.5387 \mathrm{~kg} / \mathrm{kWh}$ when the torque was $2 \mathrm{Nm}$ at $629.7 \mathrm{~W}$ and engine speed of $2982 \mathrm{rpm}$ mean exhaust temperature at this level was $127^{\circ} \mathrm{C}$. These values agree with the report by Karanja ${ }^{38}$.

The results of varying power fuel consumption using WESO-ME B5 are presented in Table 7. Values obtained using this sample were similar to those obtained for PDO, thus WESO-ME B5 is a better blend for biodiesel than WESO-ME B10. WESO-ME B5 generated $10.2 \mathrm{Nm}$ at maximum engine speed with an 
Table 6 WESO-ME B10 results of varying power fuel consumption test for $300 \mathrm{~s}$.

\begin{tabular}{|c|c|c|c|c|c|c|c|c|c|c|c|c|}
\hline Torque & $\begin{array}{l}\mathrm{MP}^{\mathrm{a}} \\
(\mathrm{W})\end{array}$ & SD & $\begin{array}{c}\mathrm{MS}^{\mathrm{a}} \\
(\mathrm{rpm})\end{array}$ & SD & $\begin{array}{l}\mathrm{ML}^{\mathrm{a}} \\
(\mathrm{N})\end{array}$ & SD & $\begin{array}{l}\mathrm{MET}^{\mathrm{a}} \\
\left({ }^{\circ} \mathrm{C}\right)\end{array}$ & SD & $\begin{array}{l}\text { MFU }^{\mathrm{a}} \\
(\mathrm{g})\end{array}$ & SD & $\begin{array}{l}\text { Fuel flow } \\
(\mathrm{g} / \mathrm{s})\end{array}$ & $\begin{array}{c}\mathrm{SFC}^{\mathrm{a}} \\
(\mathrm{kg} / \mathrm{kWh})\end{array}$ \\
\hline 8.0 & 2452.3 & 2.5 & 2957.7 & 2.1 & 8.367 & 0.058 & 195.3 & 4.5 & 49.67 & 0.31 & 0.1667 & 0.2431 \\
\hline 0.0 & 0 & 0 & 2998.7 & 1.5 & 0.033 & 0.058 & 126.3 & 1.2 & 25.07 & 0.12 & 0.0836 & 0 \\
\hline 4.0 & 1245 & 5 & 2970.3 & 2.5 & 4.197 & 0.081 & 148.7 & 1.5 & 36.47 & 0.46 & 0.1216 & 0.3515 \\
\hline 9.4 & 2985 & 5 & 2849 & 4 & 9.85 & 0.05 & 198.7 & 2.1 & 55.87 & 0.31 & 0.1862 & 0.2246 \\
\hline 2.0 & 629.7 & 1.0 & 2982 & 3 & 2.117 & 0.006 & 127 & 1 & 28.27 & 0.31 & 0.0942 & 0.5387 \\
\hline 6.0 & 1640.3 & 2.5 & 2937.3 & 2.5 & 6.30 & 0.01 & 174 & 1 & 45.13 & 0.31 & 0.1504 & 0.3302 \\
\hline
\end{tabular}

${ }^{\mathrm{a}} \mathrm{MP}=$ mean power, $\mathrm{MS}=$ mean speed, $\mathrm{ML}=$ mean load, MET = mean exhaust temp., MFU $=$ mean fuel used, $\mathrm{SFC}=$ specific fuel consumption.

Table 7 WESO-ME B5 results of varying power fuel consumption test for $300 \mathrm{~s}$.

\begin{tabular}{lcccccccccccc}
\hline Torque & $\begin{array}{c}\mathrm{MP}^{\mathrm{a}} \\
(\mathrm{W})\end{array}$ & $\mathrm{SD}$ & $\begin{array}{c}\mathrm{MS}^{\mathrm{a}} \\
(\mathrm{rpm})\end{array}$ & $\mathrm{SD}$ & $\begin{array}{c}\mathrm{ML}^{\mathrm{a}} \\
(\mathrm{N})\end{array}$ & $\mathrm{SD}$ & $\begin{array}{c}\mathrm{MET}^{\mathrm{a}} \\
\left({ }^{\circ} \mathrm{C}\right)\end{array}$ & $\begin{array}{c}\mathrm{SD} \\
\mathrm{MFU}^{\mathrm{a}} \\
(\mathrm{g})\end{array}$ & $\begin{array}{c}\mathrm{SD} \\
\text { Fuel flow }^{\mathrm{g} / \mathrm{s})}\end{array}$ & $\begin{array}{c}\mathrm{SFC}^{\mathrm{a}} \\
(\mathrm{kg} / \mathrm{kWh})\end{array}$ \\
\hline 8.67 & 2763 & 35 & 2855 & 5 & 8.55 & 0.10 & 220 & 1 & 51.33 & 0.23 & 0.1711 & 0.2229 \\
0.00 & 0 & 0 & 2999 & 1 & 0.137 & 0.025 & 120.7 & 1.5 & 26.0 & 0.2 & 0.0867 & 0 \\
4.34 & 1241 & 10 & 2925 & 5 & 4.537 & 0.064 & 128.7 & 3.1 & 36.9 & 1.7 & 0.1231 & 0.3572 \\
10.20 & 2869 & 7 & 2828.3 & 2.9 & 10.677 & 0.031 & 194 & 2 & 55.9 & 0.8 & 0.1862 & 0.2337 \\
2.17 & 622.1 & 4.2 & 2981.7 & 4.0 & 2.347 & 0.051 & 122 & 2 & 30.13 & 0.31 & 0.1004 & 0.5813 \\
6.50 & 1694.3 & 2.1 & 2912.7 & 2.5 & 6.620 & 0.046 & 171 & 1 & 44.93 & 0.42 & 0.1498 & 0.3182 \\
\hline
\end{tabular}

${ }^{\mathrm{a}} \mathrm{MP}=$ mean power, $\mathrm{MS}=$ mean speed, $\mathrm{ML}=$ mean load, MET = mean exhaust temp., MFU = mean fuel used, $\mathrm{SFC}=$ specific fuel consumption.

SFC of $0.2337 \mathrm{~kg} / \mathrm{kWh}$ and a mean exhaust temperature of $194{ }^{\circ} \mathrm{C}$. At $85 \%$ torque, output power was reduced to $2763 \mathrm{~W}$ (mean engine speed of $2855 \mathrm{rpm}$ ). The lowest torque noted occurred when the engine was set to $3 / 4$ of $85 \%$ dynamometer torque $(3 / 4 \times 85 \%$ $=0.6375)$. At this setting, the mean power generated was $622 \mathrm{~W}$ at a mean speed of $2981.6 \mathrm{rpm}$. The average exhaust temperature at this speed was $122^{\circ} \mathrm{C}$ and an SFC of $0.5813 \mathrm{~kg} / \mathrm{kWh}$.

\section{CONCLUSIONS}

Methyl esters of egusi melon dehulled seed oil (DESO-ME) and egusi whole seed oil (WESO-ME) was characterized and their biodiesel properties determined. Both samples were suitable for use as biodiesel. The methyl ester yields of DESO-ME and WESO-ME were $87.3 \%$ and $86.7 \%$, respectively. The cetane number of the WESO-ME was slightly higher than that of the DESO-ME, although both fell within the limits as defined in ASTM D6751. WESO-ME had a better kinematic viscosity $\left(4.37 \mathrm{~mm}^{2} / \mathrm{s}\right.$ at $\left.40{ }^{\circ} \mathrm{C}\right)$ than did DESO-ME $\left(4.39 \mathrm{~mm}^{2} / \mathrm{s}\right)$. The engine test bed performance of WESO-ME B5 was similar to PDO, and performances of both blends of WESOME were better than DESO-ME. Hence it is not necessary to dehull the egusi seed if it is to be utilized for the production of biodiesel, since whole seed oil methyl ester has superior biodiesel properties and performance than that from dehulled seed.

\section{REFERENCES}

1. Biswas PK, Pohit S, Kumar R (2010) Biodiesel from jatropha: Can India meet the $20 \%$ blending target? Energ Pol 38, 1477-84.

2. Demirbas A (2009) Progress and recent developments in biodiesel fuels. Energ Convers Manag 50, 14-34.

3. Pramanik P, Das P, Kim PJ (2012) Preparation of biofuel from argemone seed oil by an alternative costeffective technique. Fuel 91, 81-6.

4. Ramadhas AS, Jayaraj S, Muraleedharan C (2005) Biodiesel production from high FFA rubber seed oil. Fuel 84, 335-40.

5. Ahmad M, Zafar M, Khan MA, Sultana S (2009) Biodiesel from Pongamia pinnata L. Oil: A promising alternative bioenergy source. Energ Sourc A 31, 1436-42.

6. Rashid U, Anwar F, Moser BR, Knothe G (2008) Moringda oliefera oil: A possible source of biodiesel. Bioresour Tech 99, 8175-9.

7. Eugene NO, Gloria N (2002) Chemical composition of selected Nigerian oil seeds and physicochemical properties of the oil extracts. Food Chem 77, 431-7.

8. Oyolo OA (1977) Qualitative and quantitative study of 
seed types in Egusi melon (Citrullus colocinthis L). Trop Sci 19, 51-61.

9. Jeffrey C (1980) A review of Cucurbitaceae. Bot J Linn Soc 81, 233-47.

10. Uruakpa F, Aluko R (2004) Heat-induced gelation of whole egusi (Colocynthis citrullus L.) seeds. Food Chem 87, 349-54.

11. Giwa S, Abdullah LC, Adam NM (2010) Investigating "egusi" (Citrullus Colocynthis L.) seed oil as potential biodiesel feedstock. Energies 3, 607-18.

12. Oghonna PE, Obi I (2007) Effect of time of planting and poultry manure application in growth and yeild of Egusi melon in a derived savanna in agro-ecology. Agro-Science 6, 33-9.

13. Bande YM, Adam NM, Azmi Y, Jamarei O (2012) Moisture-dependent physical and compression properties of bittermelon (Citrullus colocinthis lanatus) seeds. Int J Agr Res 7, 243-54.

14. Oluba OM, Ogunlowo YR, Ojieh GC, Adebisi KE (2008) Physicochemical properties and fatty acids composition of (Citrullus lanatus) seed oil. J Biol Sci 8 , 814-7.

15. Freedman B, Pryde E, Mounts T (1984) Variables affecting the yeild of fatty acids from transesterified vegetable oils. J Am Oil Chem Soc 61, 1638-43.

16. Canakci M, Van-Gerpen J (1999) Biodiesel production via acid catalysis. Trans ASAE 42, 1203-10.

17. El-Dawani G, Attia NK, Hawash S (2009) Development and evaluation of biodiesel fuel and by-product from jatropha oil. Int J Environ Sci Tech 6, 219-24.

18. CEN (2012) Liquid petroleum products - Fatty acid methyl esters (FAME) for use in diesel engines and heating applications - Requirements and test methods. European Standard EN14214. European Committee for Standardization, Brussels.

19. Allen CAW, Watts KC, Ackman RG, Pegg MJ (1999) Predicting the viscosity of biodiesel fuels from their fatty acids ester composition. Fuel 78, 1319-26.

20. Schinas P, Karavalaskis C, Davaris C, Anastopoulos G, Karonis D, Zannikos F, Stournas S, Lois E (2009) Pumpkin (Cucurbita pepo L.) seed oil as an alternative feedstock forthe production of biodiesel in Greece. Biomass Bioenerg 33, 44-9.

21. Zhou A, Thomson E (2009) The development of biofuels in Asia. Appl Energ 86, S11-20.

22. Al-Khalifa AS (1996) Physicochemical characteristics, fatty acid composition, and lipoxygenase activity of crude pumpkin and melon seed oils. J Agr Food Chem 44, 964-6.

23. Milokovic M, Pucuric-Jovanovic K (2005) Characteristics and composition of melon seed oil. J Agr Sci 50, 41-7.

24. Amit P, Kachhwaha SS, Maji S, Babu MKG (2010) Thumb (Citrullus colocinthis) seed oil: A suitable source of renewable energy for biodiesel production. J Sci Ind Res 69, 384-9.

25. Robert LJ, Irvin J (2012) Oil and fatty acids contents in seed of Citrullus lanatus Schrad. J Agr Food Chem 60, 5199-204.

26. Körbitz W (1999) Biodiesel production in Europe and North America, an encouraging prospect. Renew Energ 16, 1078-83.

27. Veny H, Baroutian S, Aroua MK, Hasan M, Raman AA, Sulaiman NMN (2009) Density of Jatropha curcas seed oil and its methyl esters: Measurement and estimations. Int J Thermophys 30, 529-41.

28. Yee KF, Lee KT (2008) Palm oil as feedstock for biodiesel prodution via heterogenous transesterification: Optimisation study. In: Proceedings of the International Conference on Environment, 2008, Kuala Lumpur, Malaysia, pp 21-31.

29. Usta N (2008) Use of tobacco seed oil methyl ester in turbocharged indirect injection diesel engine. Biomass Bioenerg 28, 77-86.

30. Tsanaktsidis CG, Christidis SG, Tzilantonis GT (2010) Study about effect of processed biodiesel in physicochemical properties of mixtures with diesel fuel in order to increase their antifouling action. Int J Environ Sci Dev 1, 205-7.

31. Moser BR (2009) Biodiesel production, properties, and feedstocks. Vitro Cell Dev Biol Plant 45, 229-66.

32. Saydut A, Duz MZ, Kaya C, Kafadar AB, Hamamci C (2008) Transesterified sesame (Sesamum indicum L.) seed oil as a biodiesel fuel. Bioresour Tech 99, 6656-60.

33. Srivastava PK, Verma M (2008) Methyl ester of karanya oil as alternative renewable source energy. Fuel 87, 1673-7.

34. Ramos MJ, Fernández CM, Casas A, Rodríguez L, Pérez A (2009) Influence of fatty acid composition of raw materials on biodiesel properties. Bioresour Tech 100, 261-8.

35. Rashid U, Anwar F (2008) Production of biodiesel through base-catalysed transesterification of safflower oil using an optimized protocol. Energ Fuel 22, 1306-12.

36. Rashid U, Anwar F, Arif M (2009) Optimization of base catalytic methonolysis of sunflower (Helianthus annuus) seed oil for biodiesel production by using response surface methodology. Ind Eng Chem 48, 1719-26.

37. Sarin R, Sharma M, Sinharay S, Malhotra RK (2007) Jatropha-palm biodiesel blends: an optimum mix for Asia. Fuel 86, 1365-71.

38. Stalin N, Prabhu HJ (2007) Performance test of IC engine using karanja biodiesel blending with diesel. ARPN J Eng Appl Sci 2, no. 5, 32-4. 